DOI 10.20396/temáticas.v14i27/28.13635

\title{
IDENTIDADE ÉTNICA ITALIANA E AGROTURISMO EM Venda Nova do Imigrante, EsPírito SANTO"
}

\section{Verena Sevá Nogueira*}

Resumo: A partir de um estudo de caso desenvolvido no município de Venda Nova do Imigrante, no estado do Espírito Santo, observa-se que a prática do agroturismo tem relação com a identidade étnica de seus habitantes.

Através de uma etnografia da Festa da Polenta - uma das demonstrações da identidade étnica italiana - pretende-se discutir a relação entre as práticas do agroturismo e a construção da identidade étnica italiana.

O agroturismo desenvolvido no município não se apresenta somente como um turismo relativo ao campo ou ao homem do campo e às suas práticas, mas como um turismo referido a práticas identificadas como "típicas italianas".

Por outro lado, demonstra-se que no processo de re-invenção da identidade étnica italiana dos vendanovenses, o papel do agroturismo desponta como central, selecionando, destacando ou mesmo inventando sinais diacríticos do grupo.

Palavras-chave: Antropologia rural, grupos étnicos, turismo - zona rural - Espírito Santo (ES).

\section{1 - INTRODUÇÃo}

O sentimento de pertencer a um dado grupo de pessoas não é inato, resulta de processos de construção social nos quais sinais diacríticos são eleitos, re-significados e transformados constantemente e, através

\footnotetext{
* As reflexões apresentadas neste texto estão baseadas na dissertação de mestrado intitulada A "venda nova das imigrantes": relações de gênero e práticas sociais do agroturismo (2004), defendida junto ao programa de Mestrado em Sociologia do IFCH/Unicamp.

${ }^{*}$ Doutoranda em Antropologia Social - IFCH/Unicamp.
} 
dos quais as pessoas se identificam e/ou se distinguem uma das outras, formando os mais variados agrupamentos sociais.

Os grupos sociais, por sua vez, não são dados, não existem desde sempre e nem para sempre. Enquanto construção humana, os agrupamentos de pessoas requerem um motivo para existir, algo que proporcione aos seus integrantes identificarem-se como parte dos mesmos, e aos não integrantes, com os quais o grupo interage, a visibilidade de um grupo ao qual não pertencem.

Dentro do processo de construção de grupos sociais, situemos os grupos étnicos. Embora freqüentemente o senso comum associe a identidade étnica a uma origem comum ou a uma identidade racial, a mesma deve ser tratada com muito cuidado pelos cientistas sociais. Não devemos desconsiderar a origem (se houver) de um dado grupo étnico. Devemos, contudo, analisá-lo dentro de uma história de escolhas. Isto é, ao tratarmos da constituição, redefinição, mudanças e até desaparecimento de grupos sociais, as escolhas dos marcos constitutivos e identificadores do grupo devem ser vistas como parte de um processo histórico e social.

Nesse debate situamos a comunidade de descendentes de italianos de Venda Nova do Imigrante localizada na região serrana do Espírito Santo. Postulamos pela existência de uma relação entre a identidade étnica italiana dos vendanovenes ${ }^{1}$ e as atividades do agroturismo, modalidade de turismo rural, desenvolvida acerca de uma década no local.

A prática do agroturismo atualmente desenvolvida em Venda Nova $^{2}$ guarda uma visível relação com a identidade étnica dos seus praticantes. Não se trata somente de um turismo relativo ao campo, ao "agro" ou ao rural, mas de um turismo relativo ao homem do campo, e às suas práticas, identificadas como "típicas italianas". Olhando sob outro ângulo, notamos que no processo mesmo de re-invenção da identidade étnica italiana dos vendanovenses, o papel do agroturismo desponta como central, selecionando, destacando ou mesmo inventando sinais diacríticos do grupo.

\footnotetext{
${ }^{1}$ Nome dado aos habitantes de Venda Nova do Imigrante.

${ }^{2}$ A partir deste ponto do texto, ao me referir ao nome do município, o tratarei apenas como Venda Nova, isto visando tornar a escrita e a leitura do texto mais agradável.
} 
Através de uma breve etnografia da Festa da Polenta - uma das maiores demonstrações da identidade étnica italiana, bem como a maior festa turística de Venda Nova - pretendemos discutir a relação entre as práticas do agroturismo e a construção da identidade étnica italiana de seus moradores.

\section{Breve história da formação do núcleo de Venda Nova}

$\mathrm{Na}$ região onde se localiza atualmente o município de Venda Nova do Imigrante, ao sul do estado do Espírito Santo, o que havia até final do século XIX, eram grandes fazendas cafeeiras, de propriedade de famílias portuguesas, que tinham a mão-de-obra negra e escrava como a principal força produtiva. Nessa época, o café era o principal produto da região (ZANDONADI, 1992).

Com a implementação de políticas de imigração, pelo governo Imperial brasileiro, na segunda metade do século XIX, a então Província do Espírito Santo recebeu algumas levas de imigrantes estrangeiros, em especial, de alemães, italianos e pomeranos. (COSTA, 1981). Nesse período foram criadas três colônias de imigrantes: a de Santa Isabel, a de Santa Leopoldina e a de Rio Novo. Para este último protetorado dirigiuse grande parte dos imigrantes italianos ${ }^{3}$ que colonizaram, posteriormente, a região de Venda Nova.

A formação do núcleo de São Pedro de Venda Nova (atual município de Venda Nova do Imigrante) iniciou-se em 1891 com a chegada de imigrantes italianos que, insatisfeitos com as condições das terras no ex-núcleo Castello, as abandonaram e compraram parcelas das terras dos então decadentes fazendeiros do café de Venda Nova.

Em 1988, deu-se a constituição do município de Venda Nova do Imigrante, em decorrência de sua emancipação do município vizinho de Alfredo Chaves. Atualmente Venda Nova do Imigrante é formada pela sede urbana, por dois Distritos e por bairros rurais. Os bairros rurais de Venda Nova são chamados por seus habitantes de comunidades rurais. Tra-

\footnotetext{
${ }^{3}$ Os imigrantes italianos, provenientes da região do Trento, no norte da Itália chegaram à colônia Rio Novo a partir de 1873, principalmente entre os anos de 1875 e 1880.
} 
ta-se de uma utilização bastante disseminada localmente, seja pelas pessoas em geral, seja pelos escritos oficiais. Notamos, por exemplo, que no Plano de Desenvolvimento Rural (2000), do Incaper (Instituto Capixaba de Pesquisa e Extensão Rural), quando da apresentação dos dados populacionais, a distribuição da população é feita por comunidades e não por bairros.

Observamos que, muito embora a noção êmica de comunidade rural não coincida com as definições de bairros rurais (categorias analíticas), trazidas por Maria Izaura Pereira de Queiroz (1973) e por Antonio Candido (2001), estas podem ser tidas como marcos teóricos na definição da noção de comunidade utilizada neste texto.

Num mesmo sentido de bairros rurais analisados por Queiroz (1973), as comunidades rurais de Venda Nova podem ser entendidas como agrupamentos de pessoas que vivem em habitat dispersos, porém em espaços físicos geograficamente demarcados. Os laços de amizade, parentesco e reciprocidade atuam como fatores de delimitação do agrupamento humano das comunidades. A igreja aparece como ponto central de referência, em torno da qual se estrutura a vida comunitária.

No entanto, diferentemente dos bairros rurais estudados por Queiroz (1973) e por Candido (2001), as comunidades rurais de Venda Nova não se estruturam internamente de forma igualitária, no sentido de todos os seus moradores pertencerem a um mesmo nível sócio-econômico. As diferenças sociais internas são mais aparentes nas comunidades mais próximas da área urbana do município, assim como naquelas em que há maior diferenciação entre as atividades de seus moradores, ou seja, naquelas em que o trabalho agrícola não é a única atividade de seus habitantes. Notei a presença de pessoas destituídas de terra nas comunidades rurais de Venda Nova, fato este que, aliás, leva-nos a apreender uma diferenciação social importante, entre os proprietários de terra (os sitiantes) e os parceiros (colonos) e os assalariados rurais sem terra.

Embora o termo comunidade seja marcado pelos estudos de comunidade, que figuraram nos estudos rurais brasileiros nas décadas de 1950 e 60, tampouco é a partir da noção de comunidade presente nesses 
estudos que deve ser entendida a noção de comunidade aqui tratada ${ }^{4}$. Um dos principais fatores que distinguem o que entendemos por comunidade em Venda Nova do que os estudos de comunidade entendem como tal está no fato de que, enquanto estes nos fazem pensar uma comunidade rural como um mundo fechado em si mesmo, dotado de uma autonomia demasiada em relação ao mundo exterior, é característico das comunidades em Venda Nova, serem agrupamentos abertos com uma dinâmica de relações sociais entre o local e o "de fora".

Por fim, constatamos que a noção de comunidade é utilizada para designar tanto os grupos sociais que habitam um bairro rural, como o grupo de habitantes do município de Venda Nova. Especificamente neste texto, ao fazer referência à comunidade de descendentes de italianos, estaremos tratando dos habitantes do município como um todo, e não de um ou outro bairro rural em especial.

\section{Identidade étnica e agroturismo}

Uma dimensão importante na comunidade de Venda Nova é a da identidade étnica italiana. A herança italiana partilhada por grande parte dos habitantes de Venda Nova está presente nas práticas e representações sociais dos vendanovenses. Como exemplos de demonstração da dimensão étnica italiana, citemos a presença das cores vermelha e verde, alusivas às cores da bandeira italiana, em espaços públicos, como no logotipo da Prefeitura Municipal impresso nos carros oficiais, na pintura dos pontos de ônibus, nos ônibus escolares, e em algumas placas de sinalização. Outros exemplos são o nome de uma das faculdades existentes

\footnotetext{
${ }^{4}$ A titulo exemplificativo, citemos como estudos de comunidade, os textos:

WILLENS, Emílio. Cunha: tradição e transição em uma cultura rural no Brasil. São Paulo: Diretoria de Publicidade Agrícola da Secretaria de Agricultura, 1947.

WAGLEY, Charles. Amazon Town: a study of a man in the Tropics. New York: Macmillan Company, 1953, 315p.

PIERSON, Donald. Cruz das almas: a brazilian Village. Washington: Smithsonian Institution - Institute of Social Anthropology, n. 12, 1951.

HERMAN, Lucila. Evolução da estrutura social de Guaratinguetá num período de trezentos anos. Revista de Administração. São Paulo, ano 2, p. 1-326, março-junho de 1948.
} 
no município: Univêneto, remetendo à região do Vêneto na Itália, ou ainda, e talvez a mais visível das demonstrações da dimensão italiana, que é o próprio nome do município, com a terminação "do imigrante", numa remissão à imigração italiana na região.

No processo de implantação do agroturismo em Venda Nova, a herança italiana ganhou uma nova roupagem, adquiriu uma nova importância. Argumentamos que a partir do seu surgimento, há cerca de uma década, a dimensão da identidade étnica da comunidade local sofreu um processo de (re)construção.

A identidade étnica italiana tornou-se um valor simbólico - e econômico - a mais para os vendanovenses - em especial para os agroturistas ${ }^{5}$. Além de se configurar como um turismo relativo às pessoas do campo e dos espaços rurais, o agroturismo do local possui uma dimensão simbólica associada à herança italiana de seus praticantes.

Antes do advento do agroturismo em Venda Nova, a herança italiana dos seus habitantes e as representações simbólicas a esta associada não era valorizada, ou ao menos tão valorizada. Em conversa com alguns dos moradores mais idosos do local, verificamos ser recente a percepção e valorização da dimensão italiana em Venda Nova. Sobre o resgate da tradição italiana nos relatou uma senhora idosa moradora do local.

Sim, sim. Eles são, tem um, tem uns, uns anos pra cá que eles tão resgatando bastante coisa nossa pra, né, nossos italianos. Outro dia eu fui. Falar a verdade, acabou quase com, ninguém, ninguém preservou assim aquelas casa, aquelas coisas bonita, tá acabando tudo. E hoje, eles queria tudo aquilo de volta, mas já não tem mais jeito, né. E, uma coisa foi muito perdida, muita coisa foi perdida. $\mathrm{Na}$ casa do meu pai, mesmo, era um sonho, assim, cada coisa. Mas acabou.

[...] Não davam valor. O negócio era coisa nova. Depois, aí, aí, voltou, né, outra vez um pouco, mas aí já. Tem muita gente que preserva, né, uma coisinha, mas é pouco. Pouca coisa que tem (Dona Inês, dezembro de 2003).

${ }^{5}$ Nome dado aos produtores do agroturismo.

Temáticas, Campinas, 14(27/28):117-137, jan./dez. 2006 
Observamos, inclusive inversões na valoração da herança italiana dos vendanovenses. Embora possamos afirmar que o agroturismo contribua para o enaltecimento/valorização da origem italiana da comunidade de Venda Nova, o sentimento positivo de pertencer a uma comunidade de descendentes de italianos - a comunidade de "ítalos-brasileiros" de Venda Nova - nem sempre esteve presente, em especial, se considerarmos um importante marcador étnico, qual seja a língua italiana.

Perguntado sobre como era a vida de um descendente de italiano no Brasil, um senhor afirmou:

Veja bem, eu vez em quando eu não sei falar bem, veja bem, eu fui discriminado na minha vida, eu sou de origem italiana, eu até a idade de 18 anos só sabia falar italiano [...] eu não teve nem professor, meu professor era meu pai, ele era engenheiro, e ele me ensinou italiano e me ensinou alguma coisa. (Seu Pedro, julho de 2002).

E, sobre a vergonha em não saber falar português, são as palavras de uma senhora:

Porque o papai não deixava falar o português. Então a gente tinha, até agora, eu fui estudar em Cachoeira, né, no colégio de freira, aí todo mundo no português, eu não sabia falar português. Sabe? Então, parece até que eu tenho um pouco de trauma do italiano porque as meninas ficavam rindo de $\mathrm{mim}$, assim, né, porque eu não sabia conversar o português nada, então elas riam, né, e daí ficou marcado. Criança, né. Fica marcado dentro da gente, né. Mas eu me sinto bem, nossa, até hoje em dia não tem mais essas coisas. Graças a Deus (Dona Inês, dezembro de 2003).

O italianismo ${ }^{6}$ está fortemente associado com as formas de agroturismo praticadas. Muitos dos produtos vendidos sob o rótulo do agroturismo são remetidos simbolicamente aos produtos fabricados pelos imigrantes italianos; por outro lado, muitos outros produtos foram aprendidos em cursos, viagens à Itália, e, principalmente no contato de ${ }^{6}$ Segundo Novo Dicionário da Língua Português Aurélio Buarque de Holanda Ferreira
(1975, p.789), italianismo significa: "imitação da língua italiana ou dos costumes". 
mais de cem anos dos imigrantes italianos, e de seus descendentes, com os brasileiros ${ }^{7}$.

O que importa, entretanto, não é a origem de um produto ou de um costume apontado como "tradicional italiano", mas o fato de serem simbolizados como próprios da cultura italiana, e, dentro das relações do agroturismo, resultarem num diferencial para a valorização do turismo no local, que se configura não somente como um turismo relativo aos costumes e símbolos campestres, mas também por associação com a "tradição italiana" resultante da história da imigração italiana no local.

Esse processo de (re)construção e valorização da identidade étnica italiana de Venda Nova deve ser analisado dentro das mudanças mais globais verificadas nas mais diversas sociedades humanas. O (re)surgimento das identidades nacionais e das culturas locais é analisado por Castells (1999) dentro do que chamou de fenômeno da globalização, sendo o nacionalismo cultural uma das reações ao fenômeno da globalização, à formação de redes e fluxos de pessoais e bens e à crise da família patriarcal.

Data da época do surgimento do agroturismo, a valorização dos símbolos ligados à herança italiana em Venda Nova. Observamos, por exemplo, que a emancipação do distrito de Venda Nova, em 1988, é contemporânea ao surgimento do agroturismo na região, que teve início há cerca de uma década. E, não coincidentemente o novo município recebeu a terminação "do imigrante" no seu nome. Símbolos de italianismo com referência à Itália também ganharam corpo e visibilidade nesta época, como é o caso do uso das cores vermelha e verde em espaços público, como referido acima. Outros tantos exemplos serviriam para confirmar a contemporaneidade de uma re-invenção da cultura e tradição italiana com o surgimento do agroturismo.

\footnotetext{
${ }^{7}$ As atividades do agroturismo em Venda Nova constituem-se basicamente na produção e comercialização de gêneros alimentícios, tais como: bolos, biscoitos, macarrão, geléias, compotas, bombons, socol, queijos, iogurtes, fubá, café torrado e moído, doces em massa, dentre outros; bebidas alcoólicas como vinhos, licores e cachaças; artesanato em madeira, em pedra; bordados e costura; produção de sabonete de leite de cabra e produção de arranjos de flores, dentre outros. Existe também o turismo na modalidade de visitas a sítios e fazendas da região, para conhecer "o que não existe na cidade".
}

Temáticas, Campinas, 14(27/28):117-137, jan./dez. 2006 
A seguir, trataremos especificamente de uma das demonstrações da identidade étnica italiana da comunidade de Venda Nova, a festa da Polenta, evento inserido dentro do circuito turístico do agroturismo. Podemos apontar, certamente, esta festa como o evento social mais importante dentro do processo de (re)construção da "tradição" e identidade étnica italiana em Venda Nova, justificando, por isso, sua escolha como objeto analítico privilegiado.

\section{Festa da Polenta ${ }^{8}$}

A festa da Polenta é uma das maiores demonstrações da dimensão étnica italiana da população de Venda Nova. Em três dias de festa vendanovenses e turistas (re)constróem o que entendem como tradições e costumes italianos herdados dos primeiros imigrantes italianos que na região chegaram no final do século XIX.

A festa da Polenta foi idealizada em 1979, por um padre local, visando arrecadar dinheiro para obras beneficentes. Foi inspirada nas quermesses que os párocos da igreja matriz realizavam todo dia 12 de outubro, no dia da padroeira da cidade, Nossa Senhora Aparecida. Era um momento de encontro social importante para os vendanovenses e para seus familiares e conhecidos, que vinham de outras cidades para participar da festa.

O nome da festa faz referência a uma comida trazida pelos imigrantes italianos para a região: a polenta, produzida a partir de água, farinha de milho, água e sal. Trata-se de um alimento presente na refeição dos moradores de Venda Nova, sendo consumida basicamente de duas formas: como acompanhamento da carne ou, no café da manhã e nos lanches, com queijo. Assim relataram dois senhores já idosos:

Cedinho, 5 hora, nóis já tava tudo em pé. De manhã cedo era merenda, carne, queijo, ovos, polenta, café. Parava meia hora pro almoço. O almoço era aroiz, feijón, carne,

\footnotetext{
${ }^{8}$ A análise apresentada resultou da minha participação nos dias 11 a 13 de setembro de 2002 na festa da Polenta.
} 
verdura e polenta (depoimento oral do senhor Aldir Cesatti In LAZZARO, 1992, p. 72, grifo meu).

O feijón com aroiz dos italiano era polenta, num pudia fica sem fubá (Depoimento oral da senhora Teresa Dell'Armellina Serafini. In LAZZARO, 1992, p. 65).

Observamos, entretanto, que embora a polenta fosse um alimento consumido cotidianamente pelos descendentes de italianos de Venda Nova, antigamente não era costume servi-la em festas. Assim relataram dois outros vendanovenses já idosos:

O interessante é que a polenta que os italiano comia todo santo dia. Mas nas festa non tinha polenta, nas festa só tinha macarón, galinha assada, sopa de taiadete, porco assado, boi quando tinha, mas polenta non (Depoimento oral da senhora Justina Venturini Pasti In LAZZARO, 1992, p. 78, grifo meu)

(Ao falar sobre a comida servida numa festa de casamento) Primeiro tinha sopa de taiadela e galinha. Depois retirava os prato e servia taiadela asciuta (macarrão enxuto feito em casa sem caldo), galinha assada, carne de porco, queijo, arroz, non seria polenta. Depois vinha muitas qualidade de doce e muito vinho (Depoimento oral do senhor Natalino Spadetto In LAZZARO, 1992, p. 94, grifo meu).

Ora, não importa se a polenta era uma comida consumida antigamente nas festas ou somente nos dias comuns. O importante é a sua capacidade de funcionar como símbolo de uma festa "italiana". A escolha da polenta para o nome da festa aciona um elemento da cultura local, escolhido como marcador étnico. Este último aspecto é o ponto a destacar: a construção de uma tradição italiana ou, utilizando-me de Hobsbawn, a "invenção" de uma tradição italiana.

Ao discorrer sobre invenções de tradições, Hobsbawn (1997) afirma que, embora a recorrência ao passado seja uma característica constante, não é no passado - muitas vezes mítico - que está a explicação dessas tradições, mas no momento de sua criação. Os processos de 
criação de tradições, por isso, não se localizam num tempo passado, mas no presente. As tradições de um povo são construções sociais ocorridas num determinado período histórico e, por isso, não estiveram necessariamente sempre presentes na sua história.

Hobsbawn afirma ainda, que os processos de invenção de tradições devem ser entendidos como reações de um grupo social frente a transformações por ele enfrentadas. Frente a essas transformações o grupo faz uso de alguns (porém, não de todos) elementos simbólicos de seu passado para construir uma tradição. Dessa forma, Hobsbawn acredita que a explicação de uma tradição deve ser buscada na relação que este passado recriado mantêm com o tempo de sua criação.

Trazendo esses conceitos para a festa da Polenta, observamos que a tradição italiana, que é em todo momento referida, seja por seus organizadores, seja pelos turistas, não é um elemento essencial e a-histórico da comunidade de Venda Nova, nem da categoria genérica dos descendentes de italianos. Ela foi e é inventada continuamente pelas pessoas, e para isso se serve de elementos que simbolizam um passado italiano.

Uma das mais concorridas atrações da festa é a eleição da rainha e das princesas da Polenta. Segundo anunciado no microfone pelos organizadores do concurso, não se trata de um desfile de moda, ou de um concurso de beleza, mas um ritual de "resgate da cultura italiana". No julgamento privilegiar-se-ia, portanto, não somente na beleza e a desenvoltura da candidata, como manequim, mas a originalidade e beleza da roupa e do penteado por ela portado, dentro dos padrões entendidos como da "tradição italiana".

Em 2002 eram nove as candidatas, com idade entre 19 e 24 anos. O requisito para concorrer aos títulos de rainha ou princesa da polenta é

\footnotetext{
${ }^{9}$ Este tipo de julgamento, contudo, não é totalmente aceito pela população local. Na versão da festa da Polenta de 2003, a moça eleita como a "Rainha da Polenta" foi apontada, por várias de minhas informantes, como não merecedora do título, pois era de estatura baixa e um pouco gordinha. Isso nos leva a pensar que, embora esse concurso seja uma das atrações de uma festa "italiana", servindo como elemento de construção de uma tradição que se quer italiana, ele é visto como mais do que isso, ou seja, é tido também como um concurso de beleza, que funciona até mesmo como trampolim para muitas jovens locais, que pretendem se tornar manequins ou modelos fotográficos.
} 
ser membro de família de descendentes de italiano e residir no município de Venda Nova ou, em não residindo, um de seus pais ao menos, deve ter residência no local ${ }^{10}$. Ao som da música italiana "Finiculi funiculá" as candidatas entraram no palco. As roupas, bastante luxuosas, eram bastante parecidas entre si, apenas com variações de cor e desenhos dos bordados.

Após a apresentação individual de cada concorrente, que consistia basicamente no anúncio do nome, da idade e da profissão, era perguntado a cada uma delas o que mais valorizavam na Festa da Polenta. As respostas eram praticamente homogêneas: todas diziam que o que mais valorizavam era a cultura e a tradição italiana nela presentes.

O concurso era encarado pelos espectadores como uma reprodução do vestuário das italianas que imigraram para a região no final do século XIX. Observa-se, contudo, que as roupas apresentadas pelas concorrentes eram bastante luxuosas, roupas estas que certamente não eram as vestidas pelas camponesas italianas do meio rural da região de Venda Nova.

A forma de vestir dos imigrantes italianos era bastante simples no início da colonização italiana em Venda Nova. Segundo o relato de um neto de imigrantes italianos, o uso de sapatos estava restrito ao ambiente da igreja. Era costume carregarem nas mãos os sapatos, no percurso de casa à igreja, e somente quando chegavam lá é que os calçavam. Era essa uma forma de economizar o único par de sapatos que muitos deles possuíam. Afirmou este senhor:

Isso era um costume nosso mesmo. Meus pais fazia e nóis também. Até i na igreja ali, era costume, leva o sapato nas costa e calçá lá na igreja. Lava os pé lá perto da igreja e aí calçava o sapato e entrava na igreja. Era assim. Era um costume dos velho mesmo. (Depoimento oral do senhor Aldir Cesatti In LAZZARO, 1992, p. 70).

\footnotetext{
${ }^{10}$ Em conversa com uma moradora do local, durante a solenidade de abertura, tomei conhecimento dessas regras. Minha informante, ainda, lamentou que sua sobrinha, que tinha uns 20 e poucos anos, e era muito bonita, não pode concorrer ao título de rainha ou de princesa da Polenta, pois tanto ela, como seus pais residem em Vitória-ES.
} 
Num mesmo sentido escreveu um autor local:

De roupa, tínhamos duas mudas de vestuário para o serviço de campo, feitas de arranca-toco e mescla e que geralmente davam para passar o ano. Tínhamos ainda dois ternos para os domingos e festas religiosas e sociais, um par de sapatos e um chapéu [...]. Geralmente, saíamos de casa para a Igreja levando nas mãos os sapatos que eram calçados lá; na volta, repetia-se a operação ao inverso. O uso de calçados era mais familiar. Em casa todos tínhamos um par de sócoli ou tamanco de pau. Nossos pais eram profissionais no seu fabrico [...] Não se usava calçado no serviço da lavoura [...] (ZANDONADI, 1992, p. 136/137).

O fato das roupas apresentadas pela rainha e pelas princesas da Polenta serem ou não reproduções precisas das roupas trazidas pelas imigrantes italianas para a região, não importa para os organizadores e turistas. O que está em questão não é uma reconstrução fiel do passado, mas a "invenção de uma tradição" por meio da qual os vendanovenses constróem um sentimento de pertencimento a um grupo social (heterogêneo certamente), distinto de outros grupos sociais "de fora".

Em seguida ao concurso da rainha da Polenta, houve a apresentação de um grupo de dança, composto por oito casais de meninos e meninas, que dançavam ao som da música italiana "Esperanza". Notamos que esta foi a primeira, das muitas vezes, que essa música foi tocada na festa. Interessante é que, à época da festa, estava sendo apresentada na principal emissora de televisão aberta brasileira ${ }^{11}$, uma novela sobre imigrantes italianos de São Paulo, cujo título e música principal era "Esperanza", a mesma tocada incansavelmente durante todos os dias da festa. Observamos uma identificação dos descendentes de italianos de Venda Nova com a história dos imigrantes italianos paulistas, contada pela mencionada novela. Se as circunstâncias históricas dos imigrantes italianos, que vieram para a região de Venda Nova, eram as mesmas daquelas retratadas na televisão, isso não importa ${ }^{12}$. $\mathrm{Na}$ identificação étnica de uma comunidade - a dos descendentes de italianos de Venda Nova -

${ }^{11}$ A emissora é a Rede Globo de Televisão. 
como parte de um grupo mais geral - a dos descendentes de italianos do Brasil - as diferenças porventura existentes entre eles são desconsideradas. Numa identificação étnica, o que importa é a idéia que os membros do grupo étnico tem de sua origem comum, e não necessariamente a origem comum em si mesma.

Uma outra atração da festa foi a apresentação de um coral infantil. Uma das músicas apresentadas pelas crianças foi um rapper italiano. No primeiro dia de apresentação a menina que solava a música estava vestida como uma criança brasileira atual (bermuda, blusa de malha e tênis), contrastando com as outras crianças do coral, que trajavam vestidos e terninhos alusivos às roupas das crianças italianas do final do século XIX. No dia seguinte, esse mesmo coral infantil fez uma outra apresentação, e a menina que antes usava roupas atuais, apresentou-se vestida com a mesma roupa que as outras crianças do coral. Perguntado para um dos organizadores da festa o por quê da mudança, foi respondido que era porque a roupa atual, usada no dia anterior pela menina, descaracterizara o propósito da festa, o resgate de uma tradição italiana, e que, por isso, muitas pessoas não haviam gostado.

Ora, vemos aqui que a noção de cultura italiana construída, inventada e acreditada pelos turistas e pelos vendanovenses remonta à idéia que se faz de uma cultura e tradição italiana de fins do século XIX, de uma dada região italiana, o Vêneto, de onde veio a maior parte dos imigrantes italianos para a região.

Aliás, em todas as danças e encenações artísticas da festa, os artistas sempre usavam roupas que representavam o modo de vestir dos italianos do final do século XIX. Eles falam em resgate, preservação e propagação da cultura italiana. Perguntamos então, trata-se do resgate, preservação e propagação da cultura de quais italianos? De que época histórica? De uma época específica - final do século XIX - e de uma dada região italiana - norte da Itália. Porém, para eles - vendanovenses e turistas - isso não importa, já que a idéia de tradição e cultura italiana,

\footnotetext{
12 A característica da imigração italiana para São Paulo, conforme a novela em questão, foi o fato de que os imigrantes vieram trabalhar como colonos dos grandes cafeicultores paulistas, isto é, não adquiriram, como em Venda Nova, lotes de terra próprios.
} 
que se quer passar, é a construída socialmente pelos italianos e seus descendentes, ao longo de mais de um século. Por isso, não tem importância em quais símbolos do passado as tradições se baseiam, seja de um passado longínquo ou recente, seja de uma região da Itália ou de outra. O importante é que a tradição construída seja acreditada, pelos locais e pelos de fora, como representativa da idéia de cultura italiana.

Observamos uma criteriosa seleção de símbolos do passado, feita pelos agentes sociais, para a construção de uma tradição italiana. Questionamos, por exemplo, por que na festa da Polenta de 2002, uma das atrações anunciada como típica italiana é o jogo de moretina, enquanto que o jogo de bocha, igualmente trazido da Itália pelos imigrantes, sequer é mencionado? Observe-se que num processo de invenção de tradição, alguns elementos do acervo cultural de um grupo social são selecionados, enquanto outros "esquecidos" e que, a escolha dos marcos culturais que irão

representar uma dada tradição é o resultado de uma escolha política dentro de um grupo social (CARNEIRO DA CUNHA, 1987b).

O processo de invenção das tradições pode ser uma ação política, organizada ou não. O que importa é a repercussão popular que essa tradição deve ter para sobreviver. A sobrevivência de uma tradição depende da força de representação que os elementos simbólicos, selecionados do passado, terão no sentido de oferecer um sentimento de pertença e de integração social a um dado grupo social (HOBSBAWN, 1997).

No caso da festa da Polenta, tanto mais efeito terá a tradição italiana construída, quanto mais ela sirva de elemento de diferenciação do grupo "ítalo-brasileiro" em relação aos outros. Tanto mais sucesso terá a festa da Polenta, como uma festa "típica italiana", quanto mais representativa ela conseguir ser da idéia de tradição e cultura italiana.

Voltando ao caso dos jogos de bocha e de moretina, levantamos como hipótese para explicar porque o segundo é atração da festa e o primeiro não, o fato do jogo de moretina ter sido talvez menos apropriado pela cultura brasileira que o de bocha. Ou, em outras palavras, a representatividade do jogo de moretina, como um sinal diacrítico da identidade étnica italiana, talvez tenha sido julgada, pelos organizadores 
da festa, como mais eficaz que a do jogo de bocha, atualmente muito mais conhecido no Brasil que o de moretina.

Ligado ao aspecto da "invenção das tradições" de um grupo social, entendemos necessário discorrer sobre o que significa um grupo étnico, como ele se forma, e qual a sua relação com os marcos culturais que os distinguem de outros grupos sociais. A partir disso, perguntaríamos se a comunidade de descendentes de italianos de Venda Nova caracteriza-se como um grupo étnico ítalo-brasileiro? E, em caso afirmativo, qual o papel da festa da Polenta na afirmação da identidade étnica desse grupo?

A identidade étnica é uma das formas particulares de identidade social. O moderno entendimento de identidades pressupõe o rompimento com concepções essencialistas e com a idéia de que, longe de ser algo único, as identidades sociais são acionadas contrastivamente dependendo das situações específicas. As múltiplas configurações da identidade étnica, por sua vez, revelam sua plasticidade diante de cada grupo social e de acordo com o contexto histórico em que se insere.

A obra de Fredrik Barth (1988) é apontada pela literatura antropológica como um marco na discussão da relação entre cultura e identidade étnica. O autor critica a concepção de que o grupo étnico seria uma "unidade portadora de cultura", e afirma que uma cultura não é uma característica primordial de um grupo étnico, mas, ao contrário, o seu resultado. Um grupo étnico não se define, portanto, a partir de sua cultura, mas se caracteriza como um tipo de organização social em relação a outros grupos. Portanto, é através do processo de identificação étnica que um grupo étnico se afirma enquanto tal, e se diferencia dos outros com os quais se relaciona. É na fronteira étnica que se define um grupo étnico. Este processo de identificação dá-se pela auto-atribuição e pela atribuição étnica por outros, na interação de diferentes grupos sociais.

Roberto Cardoso de Oliveira aponta como "propriedades estruturais" do processo de identificação, tanto o seu caráter contrastivo, que se refere a definição do "nós diante dos outros", como a manipulação da identidade étnica em situações de ambigüidade. De acordo com a idéia do caráter contrastivo das identidades étnicas, Cardoso de Oliveira afirma, na mesma linha argumentativa de Barth, que "a identidade contrasti- 
va parece consistir na essência da identidade étnica" (CARDOSO DE OLIVEIRA, 1976, p.5).

Ainda nessa discussão de etnicidade, cito algumas idéias de Bartolomé (2000), inseridas dentro da mesma linha argumentativa de Barth - a de que a identidade étnica não pode ser entendida como a cultura de um grupo. Para Bartolomé, a caracterização de um grupo étnico em relação a outros grupos, no sentido da "fronteira étnica" de Barth, é um dos elementos importantes para a caracterização da etnicidade; entretanto, aponta também ser importante considerar, no processo social de identificação étnica, as relações internas de um grupo, que aparecem estruturadas com base numa complexa rede de "normas, valores, símbolos herdados, compartilhados e transmitidos que constitui a cultura" (BARTOLOMÉ, 2000, p.137).

As idéias de relações internas constitutivas de um grupo étnico, também podem ser encontradas no texto dos holandeses Vermeulem e Covers (1997). Defendem estes autores que, além da dimensão da interação da etnicidade (a identificação étnica numa relação com 'outros') presente em qualquer grupo étnico, há também a dimensão da consciência ou "estados subjetivos" dos participantes de um grupo étnico. Esses autores estão preocupados com uma disputa política interna ao grupo, na escolha, por exemplo, dos traços diacríticos do grupo. A definição de um grupo étnico estaria nesta definição, portanto, pautada também pelo sentimento de pertencimento ao grupo.

Afirma ainda Bartolomé, que os conteúdos culturais, muito embora não definam a identidade étnica de um grupo, condicionam a percepção dos limites étnicos sugeridos por Barth. Pondera que, enquanto a etnicidade é uma espécie de identidade em ação, uma "manifestação política do étnico", a cultura representa o que ele denomina por "componente civilizatório", que entraria na configuração da identidade e da etnicidade de um grupo social. "A identidade pode [...] basear-se na cultura, embora não dependa de um patrimônio cultural exclusivo" (BARTOLOMÉ, 2000, p.137). Aqui Bartolomé remete-nos à idéia de processo social de identificação, no sentido de que uma identificação étnica é 
sempre situacional, o que quer dizer que varia de acordo com o contexto em que o grupo está inserido.

Manuela Carneiro da Cunha (1987b) partilha também da idéia de que a etnicidade é distinta da cultura, muito embora reconheça que, no processo de construção da identidade étnica de um grupo ocorra uma seleção de elementos culturais dentro de um reservatório cultural. Além disso, a escolha dos tipos de "traços" culturais ${ }^{13}$ deve levar em conta o grupo ao qual se opõe, já que os sinais diacríticos selecionados pelo grupo, dentro de seu 'acervo cultural', devem poder se opor aos sinais diacríticos de mesmo tipo, presentes no outro grupo.

Carneiro da Cunha lembra ainda, que "os grupos étnicos são formas de organização que respondem às condições políticas e econômicas contemporâneas e não a vestígios de organizações passadas. Eles se servem do arsenal cultural não para conservá-los como um todo [...] mas para selecionar traços que servirão de sinais diacríticos [...]" (CARNEIRO DA CUNHA, 1987a, p. 94).

Concluí-se, a partir desses autores, que a identidade étnica é construída e perpetuada, conforme os grupos sociais são contrastados uns face aos outros. Os elementos culturais, como por exemplo, as indumentárias, funcionam como sinais diacríticos entre grupos étnicos, mas não correspondem à essência de sua identidade étnica. Os elementos culturais de um grupo étnico variam no tempo e no espaço. Em cada momento de sua história, os grupos étnicos selecionam alguns elementos culturais de seu "acervo cultural" e, através destes, identificam-se entre si e perante os outros. Também as relações internas de um grupo: suas normas, seus símbolos, seus valores, bem como o sentimento de pertencimento a um grupo étnico, são dimensões "internas" importantes.

\footnotetext{
${ }^{13}$ Reproduzimos aqui a nomenclatura 'traços culturais', encontrada nos textos referidos. Entretanto, preferimos colocá-la entre aspas, pois não pretendemos remeter a nenhuma espécie de resquício de alguma cultura perdida.
} 


\section{ConsideraÇões FINAIS}

O tema da etnicidade e tradição italiana está fortemente vinculado às atividades de agroturismo desenvolvidas no município de Venda Nova do Imigrante. Quando um turista vai a um sítio comprar uma peça de socol $^{14}$, por exemplo, ele não está interessado somente em um produto "da roça", mas em um produto que seja, tanto ligado a um mundo rural como permeado por uma idéia de tradição italiana. Trata-se, portanto, de um socol produzido a partir de uma receita trazida da Itália, por uma família de descendentes de italianos, que se estabeleceu em Venda Nova como agricultora.

A festa da Polenta é vista como uma demonstração do resgate da origem da tradição e memória italiana de grande parte dos moradores do município. Para os turistas, é uma festa que mostra os "italianos" do Brasil.

Poderia-se falar, numa análise preliminar e superficial, em apropriação comercial de um passado de colonização italiana no município, interessante para o desenvolvimento do turismo local, no sentido de uma invenção de um passado e de uma tradição italiana que passa a ser vendida aos turistas. Não obstante, um olhar mais atento nos mostra que nesse processo mesmo de (re)construção/invenção da identidade étnica italiana, grande parte da população de Venda Nova, os “italianos" do município, passam a se identificar e a valorizar um sentimento de pertencimento a um grupo étnico "diferente" (italiano), e que essa identificação passa a ser constitutiva desse grupo. Os turistas, bem como os habitantes dos municípios vizinhos, por outro lado, passam a atribuir uma identidade italiana aos habitantes de Venda Nova.

Por fim, se de um lado evidenciamos a existência de um grupo étnico italiano em Venda Nova, por outro, nosso intuito fora demonstrar que este grupo é resultado de processos de construções sociais, que no caso analisado, guarda relação com as práticas do agroturismo desenvolvidas.

${ }^{14}$ Uma espécie de salame feito com carne de porco. 
Abstract: A case study was carried out in Venda Nova do Imigrante county, at Espirito Santo State, Brazil. It was observed that the agritourism is related to the ethnical identity of the inhabitants.

Through the ethnography of the Festa da Polenta, one of the many Italian ethnical identities, it was pretended to argue the relationship between the agritourism practices and the building of the Italian ethnic identity.

The developed agritourism shows up itself not only a rural tourism or a tourism related to the country man and his practices, but a tourism related to the Italian typical customs. Otherwise, it was demonstrated that in the reinvention of Italian ethnical identity of the Venda Novenses, the agritourism role rises as the principal one, selecting, detaching or even inventing diacritics signs.

KEY-words: rural anthropology, athnico groups, tourism - rural zone - Espírito Santo (ES).

\section{REFERÊNCIAS}

BARTH, Fredrik. Grupos étnicos e suas fronteiras. In: POUTIGNAR, PH; STREIFF-FENART, J. Teorias da etnicidade. São Paulo: Editora da Unesp, 1988, p. 187-227.

BARTOLOMÉ, Miguel Alberto. Bases culturais da identidade étnica no México. In: ZARUR, Jorge de Cerqueira Leite (Org.). Região e nação na América Latina. Brasília: Editora UNB, 2000, p. 135-161.

CANDIDO, Antonio. Parceiros do Rio Bonito. São Paulo: Duas Cidades, 2001, $372 \mathrm{p}$.

CARDOSO DE OLIVEIRA, Roberto. Identidade étnica, identificação e manipulação. In: CARDOSO DE OLIVEIRA, Roberto. Identidade, etnia e estrutura social. São Paulo: Livraria Pioneira Editora, 1976, p. 1-31.

CARNEIRO DA CUNHA, Manuela. Religião, comércio e etnicidade: uma interpretação preliminar do catolicismo brasileiro em Lagos no século XIX. In: CARNEIRO DA CUNHA, Manuela. Antropologia no Brasil: mito, história, etnicidade. São Paulo: Brasiliense, 1987a, p. 85-96. 
. Etnicidade: da cultura residual mas irredutível. In: CARNEIRO DA CUNHA, Manuela. Antropologia no Brasil: mito, história, etnicidade. São Paulo: Brasiliense, 1987b, p. 97-108.

COSTA, Luciana. A colônia do Rio Novo (1854/1880). 1981. Dissertação (Mestrado em História). Instituto de Filosofia Ciências e Letras, Universidade de São Paulo.

HOBSBAWN, Eric. Introdução. In: HOBSBAWN, Eric; RANGER, Terence. A invenção das tradições. São Paulo: Paz e Terra, 1997, p. 9-23.

LAZZARO, Agostinho. Lembranças camponesas: a tradição oral dos descendentes de italianos em Venda Nova do Imigrante. Vitória: [s.n.], 1992, $330 \mathrm{p}$.

PLANO MUNICIPAL DE DESENVOLVIMENTO RURAL 2000. Venda Nova do Imigrante: Emcaper - Secretaria de Estado da Agricultura, 1999, 30p.

NOGUEIRA, Verena Sevá. A "venda nova das imigrantes": relações de gênero e práticas sociais do agroturismo. Dissertação de Mestrado. Instituto de Filosofia e Ciências Humanas, Universidade Estadual de Campinas, Campinas, 2004.

QUEIROZ, Maria Isaura Pereira. Bairros rurais paulistas. São Paulo: Livraria Duas Cidades, 1973, 157 p.

VERMEULEN, Hans; COVERS, Cora. From political mobilization to the politics consciousness. In: VERMEULEN, Hans; COVERS, Cora (Org.). The Politics of ethnic consciousness. New York: St. Martin's Press Inc., 1997, p. 1-30.

ZANDONADI, Máximo. Venda Nova do Imigrante: 100 anos da colonização italiana no sul do Espírito Santo. [Contagem]: [s.n.], 1992, 248p. 